\title{
МЕТОДИ ДОСЛІДЖЕННЯ ОПТИМІЗАЦІЇ РОБОТИ БАГАТОПРОФІЛЬНОГО МЕДИЧНОГО ЗАКЛАДУ
}

\author{
Толстанов О. К., Щиріна К. В.
}

\section{ВСТУП}

Прийняття рішення щодо оптимізації роботи багатопрофільного медичного закладу повинно відбуватися на основі аналізу інформації про діяльність закладу. В ході аналізу доцільно використовувати систему показників ефективності роботи медичного закладу та кожного відділення. Оцінювання результативності роботи можливе на основі використання найбільш ефективних методів дослідження, які прийнятні в межах вирішення конкретної проблемної ситуації.

Нині важливими проблемами багатопрофільного медичного закладу $\epsilon$ нерівномірність навантаження медичного персоналу, кваліфікація медичних кадрів, зростаюча кількість медичних даних пацієнтів i проблема автоматизації роботи медичного закладу, зношеність основних засобів і відсутність програмного забезпечення для скорочення часу на ведення первинної документації. Тому актуальним питанням $\epsilon$ розробка системи методів дослідження ефективності роботи багатопрофільного медичного закладу для формування напрямів їх оптимізації.

У зв'язку з реформуванням системи охорони здоров'я України дослідженню напрямів оптимізації роботи медичних закладів присвячено безліч наукових праць. Серед них варто виділити праці щодо окремих напрямів оптимізації роботи, які виконали Т.В. Єрошкіна, Д.В. Дерев'янко, Т.А. Зайцева, Т.О. Пилипенко, О.Ю. Качур, О.С. Ковалишин, Н.І. Іскра, В.П. Печиборщ, В.Ю. Кузьмін, В.Д. Парій, С.М. Грищук, В.М. Борис, В.М. Порохня, О.М. Горбань, Т.О. Сотникова, В.3. Стецюк, А.Й. Савицький, Т.П. Іванова, Н.В. Ольхович, Ю.О. Луговський, Р.О. Харитонюк, Н.Г. Гойда, Г.А. Мартинюк, Ю.І. Шинкарук, А.С. Янко.

У статті ${ }^{1}$ описано методи оптимізації роботи медичного персоналу терапевтичного відділення на основі аналізу ефективності його роботи

${ }^{1}$ Шинкарук Ю.І. Шляхи оптимізації роботи середнього медичного персоналу терапевтичного відділення. Медсестринство. 2018. Випуск (2). https://doi.org/ 10.11603/2411-1597.2017.2.8510. 
та подано узагальнені результати досліджень механізмів удосконалення роботи медичних установ. Н.І. Іскра, В.П. Печиборщ, В.Ю. Кузьмін ${ }^{2}$ на основі аналітичного методу обробки даних про діяльність багатопрофільних медичних закладів і статистичного аналізу у своїй роботі запропонували планування функцій та структури відділень екстреної (невідкладної) медичної допомоги багатопрофільних лікарень в Україні.

У роботі $^{3}$ використано методи нечіткої логіки, метод на основі генетичних алгоритмів і методи багатокритеріальної оптимізації для вдосконалення роботи процедурних кабінетів, лікарів, використання медичного обладнання, плану-графіку роботи клініки. У дослідженні ${ }^{4}$ проведено розрахунки та порівняння окремих показників діяльності закладів охорони здоров'я на основі методів системного аналізу, причинно-наслідкового аналізу та логічного узагальнення.

Авторами проведено аналіз технічного стану, руху основних виробничих фондів і ефективності використання основних засобів. Це дало змогу забезпечити визначення потреби в організації госпітального округу та створенні лікарні інтенсивного лікування. Нині наукові праці присвячено дослідженню окремих напрямів оптимізації роботи багатопрофільного медичного закладу. Відсутні напрацювання щодо найефективніших методів дослідження, які б дали змогу визначити напрями оптимізації роботи багатопрофільного медичного закладу. Мета роботи полягає у визначенні найбільш ефективних методів дослідження оптимізації роботи багатопрофільного медичного закладу.

2 Особливості планування функції та структури відділень екстреної (невідкладної) медичної допомоги багатопрофільних лікарень на основі досвіду США // Іскра Н.I., Печиборщ В.П., Кузьмін В.Ю. URL: http://lib.inmeds.com.ua:8080/jspui/bitstream/lib/1426/1/Особливості\%20планування\% 20функції\%20та\%20структури\%20відділень\%20ЕМД\%20багатопрофільних\%20ліка рень\%20на\%20основі\%20досвіду\%20США.pdf.

${ }^{3}$ Ковалишин О.С. Продукційна система нечіткої логіки для оптимізації планів відновлювальної терапії : дисертація на здобуття наукового ступеня кандидата технічних наук. Системи та засоби штучного інтелекту. Міністерство освіти i науки України, Національний університет “Львівська політехніка”. Львів, 2019. C. $137-148$.

${ }^{4}$ Парій В.Д. Основні підходи до визначення лікарні інтенсивного лікування при створенні госпітального округу. Україна. Здоров'я нації. 2016. № 3. С. 59-64. URL: http://nbuv.gov.ua/UJRN/Uzn_2016_3_13. 


\section{1. Основні поняття багатопрофільного медичного закладу та підходи до управління ним}

Лікарня - лікувально-профілактичний заклад, призначений для надання стаціонарної медичної допомоги хворим. Лікарня, яка надає стаціонарну медичну допомогу хворим із лікарських спеціальностей одного профілю називається однопрофільною, а з декількох лікарських спеціальностей - багатопрофільною. Відповідно до Наказу Міністерства охорони здоров'я України 28.10.2002 № $385^{5}$ багатопрофільні медичні заклади класифікуються на такі лікарняні заклади: багатопрофільні та однопрофільні, спеціалізовані та особливого типу.

До багатопрофільних належить госпіталь ветеранів війни, дитяча басейнова лікарня на водному транспорті, дитяча лікарня (республіканська, обласна, міська, районна), дитяче територіальне медичне об'єднання, дільнична лікарня (в тому числі сільських, селищних і міських рад), лікарня (республіканська, обласна, центральна міська, міська, центральна районна, районна), лікарня на водному транспорті (центральна, басейнова, басейнова, портова), лікарня на залізничному транспорті (центральна, дорожня, відділкова, вузлова, лінійна, дитяча), лікарня нафтопереробної промисловості України, лікарня професійних захворювань, лікувально-діагностичний центр, медико-санітарна частина (в тому числі спеціалізована), медичний центр (різного профілю), міська лікарня швидкої медичної допомоги, перинатальний центр зі стаціонаром, пологовий будинок (обласний, міський, районний), студентська лікарня (обласна, міська), територіальне медичне об'єднання, Національна дитяча спеціалізована лікарня “Охматдит”, Український госпіталь для воїнівінтернаціоналістів, Український державний медико-соціальний центр ветеранів війни.

У науковій літературі обгрунтовано використання різних підходів до управління в закладах охорони здоров'я: системний, програмноцільовий, орієнтований на пацієнта, процесний підхід на основі внесення інновацій та вирішення системних проблем, прагматичний підхід на основі доказової медицини. Варто також виокремити компетентісний підхід, який повинні використовувати заклади охорони

5 Про затвердження переліків закладів охорони здоров'я, лікарських, провізорських посад і посад молодших спеціалістів із фармацевтичною освітою у закладах охорони здоров'я, поточна редакція від 06.07.2018, Наказ Міністерства охорони здоров’я України 28.10.2002 № 385. URL: https://zakon.rada.gov.ua/ laws/show/z0892-02\#n28. 
здоров'я в управлінській діяльності. Всередині минулого століття в наукових роботах з управління організаціями спостерігалися якісні зрушення, що було пов'язано з використанням методології системного підходу до управління підприємствами.

Системний підхід - це напрям методології спеціального наукового пізнання та соціальної практики, в основу якого покладено дослідження об'єктів як систем ${ }^{6}$. Система - сукупність елементів, які перебувають у зв'язку та відношеннях між собою, утворюють визначену цілісність, єдність. У галузі охорони здоров'я організація процесу надання медичної послуги будується на системі виробничих відносин, ієрархічних зв'язках i на системі правил, прав, відповідальності, обов'язків.

До найефективніших інструментів управління розвитком апріорі відносять програмно-цільові підходи: стратегічне планування, кластерний і проєктний підходи для концентрації ресурсів у процесі реалізації стратегій і програм розвитку діяльності, програмно-цільове формування бюджету та інші. Ці інструменти в першу чергу орієнтовані на інноваційний розвиток, досягнення кінцевих результатів діяльності, які виражаються через задоволення потреб та інтересів закладів охорони здоров'я та отримання ними певних суспільних вигод ${ }^{7}$. Суть програмно-цільового підходу до забезпечення розвитку закладів охорони здоров'я полягає у виявленні проблем, які вимагають дослідження і ефективного вирішення, розробці стратегічних планів або відправних програм усунення перешкод на шляху досягнення поставлених цілей, формуванні відповідних напрямів управління ${ }^{8}$.

Програмно-цільовий підхід $\epsilon$ однією 3 основних форм комплексного, системного підходу до процесів управління об'єктами, процесами, відносинами різної природи та змісту, способом вирішення великих і складних завдань за допомогою вироблення та здійснення

${ }^{6}$ Допоміжний (сателітний) рахунок охорони здоров'я в Україні у 2017 році. URL: http://www.ukrstat.gov.ua.

Особливості планування функції та структури відділень екстреної (невідкладної) медичної допомоги багатопрофільних лікарень на основі досвіду США // Iскра Н.I., Печиборщ В.П., Кузьмін В.Ю. URL: http://lib.inmeds.com.ua:8080/ jspui/bitstream/lib/1426/1/Особливості\%20планування\%20функції\%20та\%20структур и\%20відділень \%20ЕМД\%20багатопрофільних\%20лікарень\%20на\%20основі\%20дос віду\%20США.pdf.

8 Аналіз стану лікувально-профілактичної допомоги населенню України // Щорічна доповідь про стан здоров'я населення, санітарно-епідемічну ситуацію та результати діяльності системи охорони здоров'я України. 2014 рік. URL: https://dspace.uzhnu.edu.ua/jspui/bitstream/lib/22921/1/РОЗДІЛ_4_Стан\%20ЛП\%20доп омоги.pdf. 
системи програмних заходів, орієнтованих на цілі, досягнення яких забезпечує розв'язання проблем, що виникли. Його застосування полягає у визначенні конкретних ресурсів для вирішення комплексних проблем, гармонізації усіх видів діяльності, активностей і заходів, які здійснюються окремими інституціями й різними рівнями управління, відстеженні результативності прийнятих рішень і виконаних завдань.

Основний акцент використання програмно-цільового підходу в державному управлінні ставиться на необхідності досягнення максимального соціально вагомого ефекту в результаті використання коштів, сплачених платниками податків. Тобто кінцевим результатом випливу програмно-цільового підходу є забезпечення рівного доступу кожному індивіду до усіх необхідних послуг належної якості. Такий підхід має бути постійним і безперервним.

Поняття “програмно-цільове управління" трактується в широкому сенсі і як метод програмного втілення управлінських рішень, і як реалізація комплексного підходу при вирішенні соціально-економічних проблем. Програму розглядають як інструмент змін, вибраний iз декількох альтернативних варіантів як найбільш ефективний шлях досягнення бажаних результатів. Поняття “цільова" передбачає спрямованість програм на досягнення заздалегідь встановленої, чітко визначеної метия.

Сутність програмно-цільового підходу полягає у використанні схеми: “проблема - мета - рішення - програма - бюджет - контроль”, тобто наявні управлінські проблеми визначають цілі їх вирішення, досягнення яких потребує певного плану заходів, складання і оптимізації бюджету та контролю його виконання. Його реалізація вимагає наявності відповідної методологічної бази, кваліфікованих фахівців i програмно обчислювальних комплексів, що за певних умов ускладнює його застосування в умовах приватних закладів охорони здоров 'я ${ }^{10}$.

На практиці програмно-цільовий підхід реалізується через регіональні цільові програми (РЦП) та забезпечує прямий зв'язок між розподілом бюджетних ресурсів і фактичними чи запланованими результатами їх використання відповідно до встановлених пріоритетів державної політики. Перевагами застосування цього методу слід зазначити створення

${ }^{9}$ Срошкіна Т.В., Дерев'янко Д.В. Аналіз стану діяльності лабораторної служби промислового регіону України та шляхи її оптимізації. Медичні перспективи. 2019. Т. 24. Випуск № 1. С. 94-100.

${ }^{10}$ Медичні кадри та мережа закладів охорони здоров'я системи МОЗ України за 2017-2018 роки. Центр медичної статистики MO3 України. URL: http://medstat.gov.ua/ukr/statdov.html. 
фінансово ресурсного забезпечення для досягнення поставлених цілей $\mathrm{i}$ гарантію цільової спрямованості їх використання.

Перспективним еволюційний шляхом розвитку закладів охорони здоров'я $\epsilon$ впровадження інноваційних підходів до управління. Розвиток інновацій - рушійна сила організаційних змін, оскільки впливає на процеси медичного обслуговування, оптимізує структуру медичних послуг. Від впровадження інновацій у медичному закладі залежить результативність зусиль щодо реформування галузі загалом. Інновації можуть виявлятися в нових процесах, методах роботи, технологіях, нових підходах до організації роботи.

Ключову організаційно-методичну роль у визначенні основних напрямів вдосконалення, розробці та реалізації інноваційних перетворень відіграють управлінські технології. У працях багатьох вчених простежується така точка зору на систему охорону здоров'я i призначення закладів медичних послуг, згідно з якою медична діяльність набуває інноваційної спрямованості. Прикладом такої точки зору може слугувати Сербія, де було успішно здійснено низку проєктів, спрямованих на створення електронної системи охорони здоров'я. Згідно з програмою підтримки, розвитку та стабілізації базових лікувально-профілактичних і фармацевтичних послуг було розроблено електронні медичні карти для закладів охорони здоров’я Сербіiі.

Базовими концепціями сучасних управлінських технологій в охороні здоров'я є системний і процесний підходи, прийняття рішень, заснованих на доказах, впровадження концепції Total Quality Management (TQM) - тотального управління якістю. Залежно від концептуальної частини розрізняють такі інноваційні підходи організаційного вдосконалення та менеджменту якості: модель TQM, організаційна самооцінка, безперервне поліпшення якості, модель Європейського фонду управління якістю - СФУЯ, модель ЕFQМ, цикл Демінга-Шухарта плануй-виконуй-перевіряй-корегуй, з яких останніми роками виокремився підхід 6 сигм, аудит зі зворотнім зв'язком. Управлінські технології розвитку здатності організації ставити i досягати цілі щодо задоволення усіх потреб зацікавлених сторін сконцентровано у вигляді фундаментальної концепції менеджменту якості або моделі ідеальних організацій.

В Україні у зв'язку з реалізацією Національної стратегії реформування системи охорони здоров'я в Україні на період 2015-2020 років ${ }^{11}$ впроваджуються нові стратегічні підходи до підвищення якості та

11 Зайцева Т.А., Пилипенко Т.О. Організація інформаційної системи "Медична картка пацієнта" Дніпропетровської обласної лікарні. Актуальні проблеми автоматизації та інформаційних технологій. Том 21. 2017. С. 87-94. 
доступності медичної допомоги та зменшення фінансових ризиків для населення, формується нова модель медичної допомоги. Нова модель охорони здоров'я передбачає спрямування усіх напрямів медицини до нового рівня якісного обслуговування та сучасних вимог європейського рівня. Одним із напрямів змін $є$ автономізація постачальників медичної допомоги, перетворення лікарень у комунальні неприбуткові підприємства.

Для контролю за діяльністю медичного закладу формуються спостережні та наглядові ради, до яких входитимуть представники медичного закладу, органи місцевого самоврядування, місцеві депутати та представники громади. Інструменти, які нині мають головні лікарі та керівники медичних закладів приватної форми власності, так само матимуть і керівники державних і комунальних лікарень.

У результаті проведення реформ зростатиме якість медичних послуг державних i комунальних закладів охорони здоров'я, ефективність організації ї роботи. Тому зростатиме й рівень конкуренції в галузі медицини. На основі прагматичного підходу та доказової медицини в Україні запроваджуватиметься державно-приватне партнерство, особливо у сфері лабораторної діагностики. Для закладів охорони здоров'я відкриваються нові механізми залучення фінансових ресурсів, серед яких співпраця з благодійними фондами та організаціями, розвиток співпраці зі страховими компаніями, міжнародними організаціями, які працюють у сфері надання медичних послуг i модернізації систем управління медициною, створення підрозділів лікарні, які працюють на комерційних принципах, розвиток діяльності лікарняних кас ${ }^{12}$.

Робота в складних умовах реформування вимагає наявності у керівників закладів охорони здоров'я певного арсеналу особистих $\mathrm{i}$ професійних якостей, відсутність яких призводить до формування численних управлінських обмежень i $\epsilon$ перешкодою на шляху модернізації галузі. Інші дослідження також підтверджують неефективність управління закладами охорони здоров'я через наслідки управлінської діяльності пострадянської адміністративно-командної моделі за принципом згори-вниз ${ }^{13}$.

12 Ковалишин О.С. Продукційна система нечіткої логіки для оптимізації планів відновлювальної терапії : дисертація на здобуття наукового ступеня кандидата технічних наук. Системи та засоби штучного інтелекту. Міністерство освіти і науки України, Національний університет “Львівська політехніка”. Львів, 2019. С. 137-148.

${ }^{13}$ Ковалишин О.С. Продукційна система нечіткої логіки для оптимізації планів відновлювальної терапії : дисертація на здобуття наукового ступеня кандидата технічних наук. Системи та засоби штучного інтелекту. Міністерство освіти і науки України, Національний університет “Львівська політехніка”. Львів, 2019. C. $137-148$. 
Нині у повсякденній професійній діяльності керівників закладів охорони здоров'я переважає господарча та фінансова діяльність, а також забезпечення закладу необхідними для діяльності ресурсами (сукупна частка таких видів діяльності найбільша - 39,97\%). Це кореспондується 3 дослідженнями інших українських фахівців, згідно з якими у діяльності головних лікарів переважає господарча робота, а не творча управлінська діяльність ${ }^{14}$.

\section{2. Мережа закладів охорони здоров'я в Україні та витрати на їх утримання в період 2010-2018 років}

У 2010-2017 роках витрати на охорону здоров'я за провайдерами (постачальниками послуг) в Україні зросли вна 165,17\%, зокрема витрати на фінансування багатопрофільних медичних закладів на 114,93\%. Тому оптимізація роботи медичних закладів повинна включати оптимізацію формування, використання, розподілу фінансових ресурсів для забезпечення зростання ефективності діяльності лікарень.

У табл. 1 відображено динаміку поточних витрат на охорону здоров'я за провайдерами (постачальниками послуг) в Україні у 2010-2017 роках.

Таблиця 1

Динаміка поточних витрат на охорону здоров'я за провайдерами (постачальниками послуг) в Україні у 2010-2017 роках

\begin{tabular}{|c|c|c|c|c|c|c|c|c|c|c|}
\hline \multirow{2}{*}{$\begin{array}{c}\text { Провайдери } \\
\text { (постачальники послуг) }\end{array}$} & \multicolumn{2}{|c|}{2010} & \multicolumn{2}{|c|}{2015} & \multicolumn{2}{|c|}{2016} & \multicolumn{2}{|c|}{2017} & \multicolumn{2}{|c|}{$\begin{array}{c}\text { ТемII } \\
\text { росту, } \%\end{array}$} \\
\hline & $\begin{array}{c}\text { млН } \\
\text { грн }\end{array}$ & $\%$ & $\begin{array}{l}\text { млн } \\
\text { грн }\end{array}$ & $\%$ & $\begin{array}{c}\text { млН } \\
\text { грн }\end{array}$ & $\%$ & $\begin{array}{l}\text { мЛн } \\
\text { грн }\end{array}$ & $\%$ & $\begin{array}{l}\text { млН } \\
\text { грн }\end{array}$ & $\%$ \\
\hline Лікарні & $\begin{array}{l}\frac{a}{a} \\
\stackrel{2}{m} \\
m\end{array}$ & $\stackrel{\text { ले }}{\text { च }}$ & 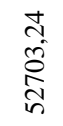 & $\begin{array}{c}m \\
m \\
m\end{array}$ & $\begin{array}{l}\infty \\
\stackrel{2}{n} \\
\hat{n}\end{array}$ & $\stackrel{n}{m}$ & $\frac{\infty}{0}$ & n & $\begin{array}{l}\Omega \\
\Xi \\
\Xi\end{array}$ & $\begin{array}{l}\mathfrak{n} \\
\infty \\
\frac{1}{1}\end{array}$ \\
\hline $\begin{array}{l}\text { Сестринські / лікарняні } \\
\text { заклади довготривалого } \\
\text { перебування }\end{array}$ & $\frac{\text { ले }}{2}$ & $\begin{array}{l}n \\
\infty \\
\dot{f}\end{array}$ & 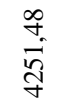 & $\begin{array}{l}n \\
\infty \\
i \\
i\end{array}$ & 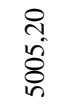 & i & $\begin{array}{l}n \\
\tilde{8} \\
\dot{8}\end{array}$ & बे & 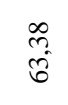 & ले \\
\hline $\begin{array}{l}\text { Заклади, які надають } \\
\text { амбулаторні медичні } \\
\text { послуги }\end{array}$ & $\begin{array}{l}8 \\
\text { ปิ } \\
\text { = }\end{array}$ & $\begin{array}{l}\infty \\
\stackrel{-}{-}\end{array}$ & \begin{tabular}{l}
$n$ \\
\multirow{2}{n}{} \\
$\infty$ \\
$\infty$ \\
$\infty$
\end{tabular} & $\begin{array}{l}7 \\
\vec{j} \\
-1\end{array}$ & 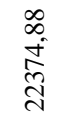 & o & 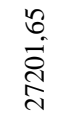 & $\begin{array}{l}0 \\
i \\
i\end{array}$ & 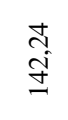 & $\begin{array}{l}n \\
\infty \\
i\end{array}$ \\
\hline
\end{tabular}

14 Качур О.Ю. Оцінка організаторами охорони здоров'я стану та перспектив розвитку променевої діагностики у закладах охорони здоров'я вторинного рівня // Україна. Здоров'я нації. Випуск 4/1(41). 2016. С. 122-126. 
Закінчення таблиці 1

\begin{tabular}{|c|c|c|c|c|c|c|c|c|c|c|}
\hline \multirow{2}{*}{$\begin{array}{c}\text { Провайдери } \\
\text { (постачальники послуг) }\end{array}$} & \multicolumn{2}{|c|}{2010} & \multicolumn{2}{|c|}{2015} & \multicolumn{2}{|c|}{2016} & \multicolumn{2}{|c|}{2017} & \multicolumn{2}{|c|}{$\begin{array}{c}\text { Темі } \\
\text { росту,\% }\end{array}$} \\
\hline & $\begin{array}{l}\text { млн } \\
\text { грн }\end{array}$ & $\%$ & $\begin{array}{l}\text { млн } \\
\text { грн }\end{array}$ & $\%$ & $\begin{array}{l}\text { млн } \\
\text { грн }\end{array}$ & $\%$ & $\begin{array}{l}\text { млн } \\
\text { грн }\end{array}$ & $\%$ & $\begin{array}{c}\text { млн } \\
\text { грн } \\
\end{array}$ & $\%$ \\
\hline $\begin{array}{l}\text { Роздрібний продаж та інші } \\
\text { організації, які надають } \\
\text { медичні товари }\end{array}$ & 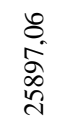 & $\begin{array}{l}\dot{1} \\
\text { i } \\
\text { m }\end{array}$ & $\begin{array}{l}\text { o. } \\
\text { مें } \\
\text { oे } \\
\text { in }\end{array}$ & \begin{tabular}{|l}
$\bar{\lambda}$ \\
$\infty$ \\
$\infty$ \\
$\cdots$
\end{tabular} & $\begin{array}{l}\text { जे } \\
\text { ते } \\
\text { ते }\end{array}$ & $\begin{array}{l}1 \\
\vdots \\
0 \\
q\end{array}$ & $\begin{array}{l}\frac{m}{1} \\
\infty \\
\frac{\infty}{2}\end{array}$ & से & 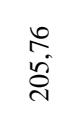 & $\mid \begin{array}{l}8 \\
i \\
n \\
n\end{array}$ \\
\hline $\begin{array}{l}\text { Забезпечення управління } \\
\text { програмами громадського } \\
\text { здоров'я }\end{array}$ & $\begin{array}{l}\text { ठ } \\
\text { gें } \\
\text { ते }\end{array}$ & $\begin{array}{l}\infty \\
n \\
i\end{array}$ & $\stackrel{\hat{N}}{\stackrel{F}{\Xi}}$ & ה. & 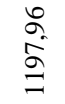 & : & $\begin{array}{l}\hat{a} \\
\text { ò } \\
\text { aे }\end{array}$ & b. & 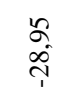 & $\underset{\sim}{\vec{\gamma}}$ \\
\hline $\begin{array}{l}\text { Загальне управління } \\
\text { охороною здоров'я та } \\
\text { медичне страхування }\end{array}$ & 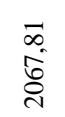 & $\begin{array}{l}0 \\
n \\
i \\
i\end{array}$ & $\begin{array}{l}\stackrel{a}{a} \\
\stackrel{8}{n} \\
\stackrel{n}{=}\end{array}$ & $\frac{\sqrt{2}}{4}$ & 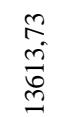 & $\stackrel{\infty}{\infty}$ & 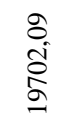 & $\stackrel{2}{2}$ & $\begin{array}{l}\infty \\
\infty \\
\infty\end{array}$ & $\begin{array}{l}\vec{n} \\
\hat{n} \\
\hat{n}\end{array}$ \\
\hline Всі інші сектори економіки & $\begin{array}{l}\underbrace{}_{0} \\
\infty \\
\infty \\
\infty\end{array}$ & $\because$ & $\begin{array}{l}\text { \& } \\
\stackrel{\text { ஸे }}{\sim}\end{array}$ & $\frac{n}{0}$ & $\stackrel{a}{a}$ & กิ & $\begin{array}{l}\infty \\
0 \\
0 \\
0\end{array}$ & \begin{tabular}{l}
$\infty$ \\
\multirow{2}{*}{} \\
0
\end{tabular} & ڤे & $\begin{array}{l}n \\
n \\
2 \\
\tilde{\delta} \\
n\end{array}$ \\
\hline $\begin{array}{l}\text { Заклади, які надають } \\
\text { послуги, пов’язані з } \\
\text { охороною здоров'я }\end{array}$ & \& & 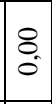 & 8 & 8 & 8 & \& & 8 & 8 & ' & \\
\hline Інший світ & 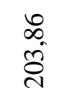 & 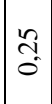 & $\begin{array}{l}: \\
\stackrel{8}{+} \\
\stackrel{\sim}{n}\end{array}$ & $\begin{array}{l}0 \\
? \\
0 \\
0\end{array}$ & $\begin{array}{l}\infty \\
\hat{\varnothing} \\
\varrho\end{array}$ & 5: & $\begin{array}{l}0 \\
0 \\
0 \\
0 \\
0\end{array}$ & 8 & 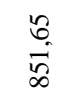 & $\mid \begin{array}{l}\infty \\
+ \\
\infty \\
0 \\
\\
\text { and }\end{array}$ \\
\hline $\begin{array}{l}\text { Провайдери, } \\
\text { не визначені за типом }\end{array}$ & $\begin{array}{l}\text { Ji } \\
\text { బิ }\end{array}$ & 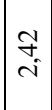 & 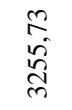 & $\frac{\infty}{i}$ & $\begin{array}{l}\infty \\
\frac{\infty}{\infty} \\
\vec{\sigma}\end{array}$ & $\underset{i}{q}$ & $\begin{array}{l}\text { ri } \\
\text { in } \\
\text { in }\end{array}$ & in & $\begin{array}{l}\infty \\
\infty \\
\stackrel{\sim}{\Lambda}\end{array}$ & 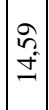 \\
\hline $\begin{array}{l}\text { Поточні витрати на } \\
\text { охорону здоров’я }\end{array}$ & $\begin{array}{l}\stackrel{m}{1} \\
\dot{f} \\
\infty \\
\infty\end{array}$ & 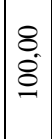 & $\begin{array}{l}\tilde{n} \\
\hat{\sigma} \\
\frac{a}{9}\end{array}$ & $\begin{array}{l}8 \\
8 \\
8 \\
-1\end{array}$ & 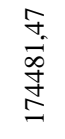 & $\begin{array}{l}8 \\
\stackrel{8}{8}\end{array}$ & $\begin{array}{l}\stackrel{?}{\sim} \\
\stackrel{\sim}{\sim} \\
\stackrel{\sim}{v}\end{array}$ & 8 & ב & 8 \\
\hline
\end{tabular}

Джерело: складено автором на основі джерела ${ }^{15}$

У роботі ${ }^{16}$ доведено, що скорочення витрат пацієнтів на лікування та зростання спеціального фонду фінансування медичного закладу

15 Допоміжний (сателітний) рахунок охорони здоров'я в Україні у 2017 році. URL: http://www.ukrstat.gov.ua. 
зумовлює зростання користі функціонування закладу та його рентабельності. Для моделювання рентабельності медичного закладу використано метод сценаріїв та оцінено ефективність кожного сценарію фінансування закладу.

Крім цього, використано методи економічного аналізу основних показників ефективності роботи медичного закладу: кількість пацієнтів (оздоровлених та тих, які померли, обсяги фінансування медикаментів за рахунок загального та спеціального фонду, витрати медичного закладу на забезпечення лікувального процесу. Для відображення моделі функціонування медичного закладу використано функцію корисності ${ }^{17}$. Отже, це дає підстави стверджувати, що одним з напрямів оптимізації роботи закладу $є$ фінансове забезпечення, яке потребує використання економіко-математичних методів i моделей, що відображають ефективність лікування та рентабельність закладу.

Станом на 31.12.2018 року в Україні функціонувало 1416 лікарняних закладів (рис. 1).

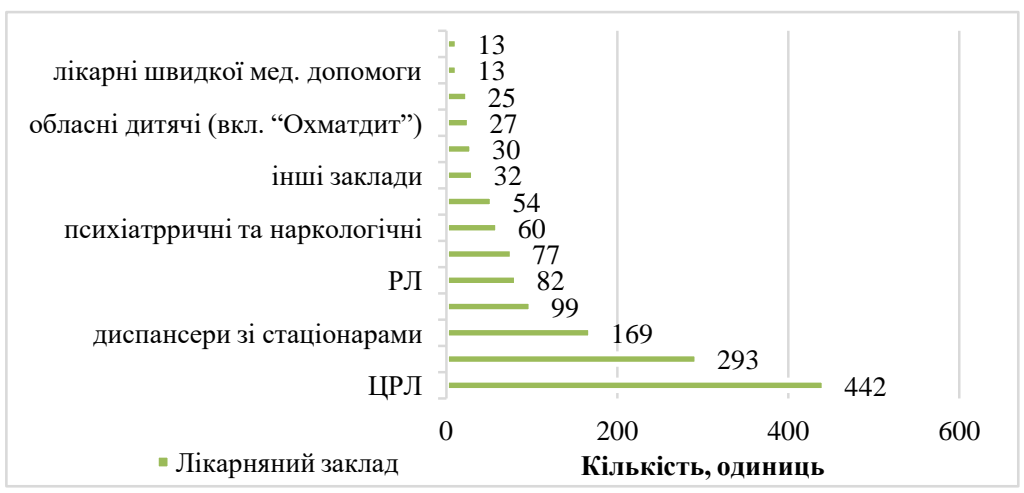

\section{Рис. 1. Мережа закладів системи МО3, які надають стаціонарну Джерело: ${ }^{18,19}$ допомогу (станом на 31.12.2018)}

${ }^{16}$ Порохня В.М. Модель максимізації функції корисності діяльності установи на основі сценаріїв розвитку. Держава та регіони: серія економіка та підприємництво. 2016. Випуск 6(93). С. 77-81.

${ }^{17}$ Порохня В.М. Модель максимізації функції корисності діяльності установи на основі сценаріїв розвитку. Держава та регіони: серія економіка та підприємництво. 2016. Випуск 6(93). С. 77-81.

${ }_{18}$ Медичні кадри та мережа закладів охорони здоров'я системи MO3 України за 2017-2018 роки. Центр медичної статистики MO3 України. URL: http://medstat.gov.ua/ukr/statdov.html. 
Кількість закладів, які надають медичну допомогу здебільшого сільському населенню (станом на 31.12. 2018), становила 442 ЦРЛ, 82 РЛ, 13 ДЛ, 3870 лікарень амбулаторій у селі, 565 ЦПМСД. Всього мережа закладів охорони здоров'я системи МО3 України станом на 31.12.2018 налічує 3358 закладів ${ }^{20}$.

Загалом по Україні спостерігається поступове зменшення лікарняних закладів на 55,5\%, а кількість пацієнтів на 1 ліжко зросла на 70,8\% у зв'язку із централізацією і закриттям малопотужних лікарень на сільських лікарських дільницях. Невдоволення лікарського і середнього медичного персоналу реальними умовами роботи з використанням зношеної техніки, відсутність належної уваги до технічного іiі обслуговування і низький рівень доходів призводять до постійного відтоку кадрів. Все це свідчить про нагальну необхідність оптимізації структури та функцій багатопрофільного медичного закладу.

\section{3. Напрями та методи оптимізації роботи}

\section{багатопрофільного медичного закладу}

Оптимізація роботи багатопрофільних медичних закладів повинна включати забезпечення зростання ефективності їх діяльності в таких основних напрямах: налагодження співпраці 3 контрагентами; оптимізація роботи персоналу, підбір кадрів і формування команд, оплата їх праці відповідно законодавству, забезпечення підвищення кваліфікації та навчання медичних працівників; техніко-технологічне забезпечення діяльності багатопрофільних медичних закладів, яке передбачає відповідність обладнання та приміщення діючим правовим нормам; автоматизовані методи лабораторної діагностики, які можуть давати високу продуктивність; інтеграція інформаційних систем із державними електронними сервісами в галузі охорони здоров'я.

Оптимізація роботи персоналу повинна відбуватися на основі використання системного підходу та передбачати використання маркетингових технологій i сучасних концепцій менеджменту. Координація діяльності персоналу повинна здійснюватися фахівцем із вищою освітою в галузі управління та менеджменту, який володіє

${ }^{19}$ Медичні кадри та мережа закладів охорони здоров'я системи MO3 України за 2016-2017 роки. Центр медичної статистики MO3 України. URL: http://medstat.gov.ua/ukr/statdov.html.

${ }^{20}$ Медичні кадри та мережа закладів охорони здоров'я системи MO3 України за 2017-2018 роки. Центр медичної статистики MO3 України. URL: http://medstat.gov.ua/ukr/statdov.html. 
лідерськими якостями; тестування медичних фахівців має проводитися не рідше разу на рік, проведення систематичних занять щодо підвищення кваліфікації для роботи у відділенні багатопрофільного медичного закладу ${ }^{21}$.

Оптимізація роботи персоналу багатопрофільного медичного закладу повинна відбуватися на основі аналізу інформації про існуючі функції та структуру відділень закладу на основі використання даних про штат, завантаженість медичних кадрів у різні періоди роботи залежно від місця знаходження медичного закладу.

Використання у процесі перспективного планування діяльності відділень багатопрофільного медичного закладу матеріалів для статистичного аналізу роботи за попередні роки повинно забезпечити скорочення навантаження на медичний персонал, від чого залежить ефективність лікувального процесу. Створення комфортних умов для пацієнтів і роботи персоналу, забезпечення необхідною нормативноправовою базою і сучасними засобами діагностики та лікування на фоні постійного професійного зростання співробітників відділень забезпечуватиме успіх в організації роботи медичного закладу. У багатопрофільному медичному закладі повинна бути створена оптимальна структура та штатний розпис відділень.

У роботі $^{22}$ запропоновано використання системного підходу до оптимізації роботи медичного закладу. Це передбачатиме вдосконалення існуючої моделі управління багатопрофільним медичним закладом, що включає підготовку кадрів (довузівську, вузівську і післядипломну); 100\% забезпеченість кваліфікованими кадрами (фізичними особами); інвентаризацію наявного обладнання; атестацію робочих місць; розробку реальної цільової програми забезпечення високотехнологічним сучасним обладнанням iз кваліфікованим сервісним обслуговуванням; заміни зношеної лабораторної техніки; вирішення питань матеріально-технічного забезпечення та раціонального фінансування багатопрофільного медичного закладу; стандартизації лабораторних досліджень i медичних послуг; створення стандартних операційних процедур (СОП); підготовки до акредитації.

${ }^{21}$ Шинкарук Ю.І. Шляхи оптимізації роботи середнього медичного персоналу терапевтичного відділення. Медсестринство. 2018. Випуск (2). URL: https://doi.org/10.11603/2411-1597.2017.2.8510.

${ }^{22}$ Єрошкіна Т.В., Дерев'янко Д.В. Аналіз стану діяльності лабораторної служби промислового регіону України та шляхи ії оптимізації. Медичні перспективи. 2019. Т. 24. Випуск № 1. С. 94-100. 
Серед методів дослідження оптимізації роботи медичного закладу варто виокремити системний аналіз для проведення кількісної і якісної оцінки проблем багатопрофільного медичного закладу, існуючих недоліків і позитивного досвіду в системі підготовки кадрів, формуванні ефективної команди працівників, поліпшенні якості медичних послуг, які надаються, шляхів оптимізації роботи багатопрофільного медичного закладу; медичної статистики: аналіз динамічних рядів за кількісними показниками (інтенсивними, екстенсивними, середніми темпами приросту / збитку лікарень, лікарняних ліжок, амбулаторно-поліклінічних закладів, клінічних лабораторій, їх кадрів, проведених аналізів) для інтерпретації результатів дослідження; логічного моделювання - для розробки концепції удосконалення діяльності багатопрофільного медичного закладу.

На рис. 2 відображено схему послідовності використання методів дослідження оптимізації роботи багатопрофільного медичного закладу.

Системний аналіз

Аналітичний метод збору інформації про ефективність медичного закладу та окремих відділень, функцій та структури відділень багатопрофільного медичного закладу, недоліки роботи, швидкості комунікації між відділеннями, структури закладу, ефективності використання наявного обладнання та роботи інформаційних систем

\section{Методи медичної статистики}

Аналіз кількісних показників роботи: середні темпи приросту лікарняних ліжок, пацієнтів, медичних закладів, медичних кадрів, проведених аналізів, кількості хворих пацієнтів, рецидивів тощо

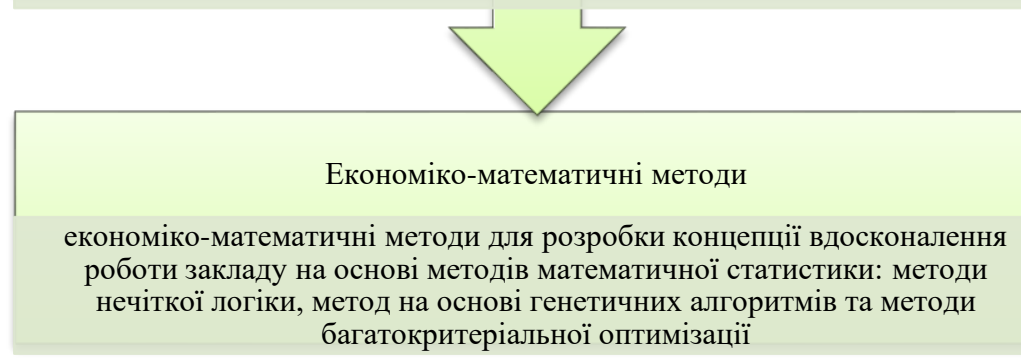

Рис. 2. Схема послідовності використання методів дослідження 


\section{оптимізації роботи багатопрофільного медичного закладу}

Джерело: розроблено авторами

Ефективним методом дослідження успішності роботи багатопрофільного медичного закладу є соціологічне опитування, яке дає змогу визначити найкритичніші проблеми медичного закладу. Згідно проведеного опитування ${ }^{23}$ було визначено, що основними проблемами закладів охорони здоров'я $€$ недостатнє фінансування, відсутність сучасного обладнання, низький рівень знань лікарями клінічних протоколів, безвідповідальність за невиконання галузевих стандартів медичної допомоги, недосконала нормативна база ${ }^{24}$. Серед методів дослідження оптимізації роботи варто виділити автоматизовані методи обробки медичної інформації, які інтегровані в інформаційні системи медичного закладу та дають змогу швидко здійснити пошук даних про пацієнта, історію хвороби та лікування.

Впровадження технологій обробки даних у вигляді реалізації сукупності методів пошуку та обробки даних суттєво спрощують ведення первинної облікової документації про пацієнта та слугують базами даних для аналізу ефективності роботи медичного закладу. Автоматизація ведення первинної документації дає змогу скоротити час медичного персоналу на ведення рутинних операцій і збільшити час на лікувальний процес. Автоматизація методів дослідження ефективності лікування пацієнтів та автоматизація обробки первинної документації загалом забезпечують оптимізацію роботи багатопрофільного лікувального закладу.

У роботі $^{25}$ наведено нове програмне забезпечення PatientCard картка пацієнта, яка виконує функції обчислення, спостереження, запам'ятовування, комунікації, інформування, регулювання та оптимізації. Оптимізаційна функція передбачає ведення оптимальних розрахунків за умов зміни медичної інформації, а тому оптимізує роботу персоналу. Крім того, важливими функціями $є$ аналізаторна -

${ }^{23}$ Качур О.Ю. Оцінка організаторами охорони здоров'я стану та перспектив розвитку променевої діагностики у закладах охорони здоров'я вторинного рівня // Україна. Здоров'я нації. Випуск 4/1(41). 2016. С. 122-126.

${ }^{24}$ Качур О.Ю. Оцінка організаторами охорони здоров'я стану та перспектив розвитку променевої діагностики у закладах охорони здоров'я вторинного рівня // Україна. Здоров'я нації. Випуск 4/1(41). 2016. С. 122-126.

25 Зайцева Т.А., Пилипенко Т.О. Організація інформаційної системи “Медична картка пацієнта" Дніпропетровської обласної лікарні. Актуальні проблеми автоматизації та інформаційних технологій. Том 21. 2017. С. 87-94. 
визначення основних показників медичної діяльності, а також документальна - формування обліково-звітних документів.

Для оптимізації роботи лаборантів і лікарів у роботі ${ }^{26}$ здійснено огляд розробленого програмного забезпечення для збереження, редагування, видалення, виведення, пошуку, обробки даних, відстеження змін, створення документів і статистичних підрахунків. Додаток прискорює процес, який розпочинається обстеженням пацієнта та закінчується отриманням усіх його аналізів. Витрачається менше часу на введення даних у форму, а завдяки словникам зменшується можливість помилки. Пошук і статистика дозволяють швидко знайти інформацію по одному чи групі пацієнтів, які мають спільні дані. Завдяки використанню одного серверу бази даних із додатком можуть працювати відразу декілька людей і отримувати останню введену інформацію.

Автоматичне створення документів позбавляє лікарів необхідності вводити результати аналізів вручну. Тому завдяки цій розробці підвищується працездатність лаборантів i лікарів, зменшується можливість помилки, витрачається менше часу на пошук інформації та формування звітів.

Автоматизація роботи медичного персоналу забезпечує оптимізацію багатопрофільного медичного закладу. Впровадження інформаційних систем у відділення багатопрофільної лікарні забезпечить швидку комунікацію між відділеннями, мінімізує виникнення помилок, забезпечить швидкість обробки інформації про пацієнта, формування всієї необхідної інформації про роботу медичного закладу, накопичення, зберігання та відновлення інформації, забезпечить швидкий доступ при першій необхідності незалежно від місця лікування пацієнта.

Методи дослідження роботи багатопрофільного медичного закладу згідно спеціалізації можна умовно поділити на такі напрями: інформаційний, який передбачає оцінку ефективності та стану інформаційних систем медичного закладу, оптимізацію та автоматизацію роботи інформаційних систем; фінансовий, який передбачають оцінку ефективності використання фінансових ресурсів медичного закладу та шляхів їх оптимізації; кадровий, що передбачає аналіз кількісних та якісних показників роботи медичних кадрів, програм підвищення кваліфікації і тестування персоналу, оцінку рівня навантаження на працівників та шляхи оптимізації їх роботи; сервісний, що передбачає оцінку ефективності лікувального процесу, лікування пацієнтів, обслуговування пацієнтів та шляхи оптимізації.

26 Стецюк В.3. Інформаційна система для медико-генетичної лабораторії. Медична інформатика та інженерія. 2016. Випуск 2. С. 55-57. 


\section{ВИСНОВКИ}

Проведене дослідження дає змогу стверджувати про доцільність використання системного підходу при виборі методів дослідження роботи багатопрофільного медичного закладу.

Система методів повинна включати методи оцінки фінансового стану, рівня сервісу медичного закладу, кадрового забезпечення та якості роботи медичного персоналу, стану інформаційних систем та обладнання, що суттєво полегшує роботу лікарів і скорочує час на діагностику та лікування пацієнтів.

Серед пріоритетних методів дослідження - методи системного аналізу, які включать оцінювання кількісних та якісних показників роботи багатопрофільного медичного закладу. Для комплексного дослідження роботи медичного закладу доцільно використовувати методи економіко-математичного моделювання.

\section{АНОТАЦІЯ}

У статті доведено, що дослідження роботи багатопрофільного медичного закладу повинно розпочинатися 3 вибору методів дослідження та базуватися на кількісних та якісних показниках його функціонування. Запропоновано схему послідовності використання методів дослідження для якісної оцінки функціонування багатопрофільного медичного закладу.

Визначено, що найпоширенішими методами дослідження роботи $\epsilon$ методи системного аналізу, які включають аналіз кількісних та якісних показників, зокрема стану основних засобів та обладнання, наявності інформаційних систем обробки медичних даних пацієнтів; кількості хворих та оздоровлених; функцій і структури відділень медичного закладу; кількість медичних кадрів і показники їх навантаження в різні часові періоди; фінансові ресурси багатопрофільного медичного закладу.

На основі методів системного аналізу доцільно оцінювати ефективність роботи багатопрофільного медичного закладу 3 використанням методів економіко-математичного моделювання: нечіткої логіки, генетичних алгоритмів, методів багатокритеріальної оптимізації. Зазначені методи дають змогу комплексно оцінити роботу багатопрофільного медичного закладу та напрями оптимізації, які можна поділити на інформаційний, фінансовий, кадровий i сервісний. Системний підхід до використання вказаних методів забезпечить комплексне вирішення головних проблем, які перешкоджають ефективній роботі багатопрофільного медичного закладу. Крім цього зазначені методи дадуть змогу здійснити автоматизацію лікувальних процесів. 


\section{ЛITЕРАТУРА}

1. Аналіз стану лікувально-профілактичної допомоги населенню України // Щорічна доповідь про стан здоров'я населення, санітарноепідемічну ситуацію та результати діяльності системи охорони здоров'я України. 2014 рік. https://dspace.uzhnu.edu.ua/jspui/ bitstream/lib/22921/1/РОЗДІЛ_4_Стан\%20ЛП\%20допомоги.pdf.

2. Допоміжний (сателітний) рахунок охорони здоров'я в Україні у 2017 році. URL: http://www.ukrstat.gov.ua.

3. Єрошкіна Т.В., Дерев'янко Д.В. Аналіз стану діяльності лабораторної служби промислового регіону України та шляхи іiі оптимізації. Медичні перспективи. 2019. Т. 24. Випуск № 1. С. 94-100.

4. Зайцева Т.А., Пилипенко Т.О. Організація інформаційної системи "Медична картка пацієнта" Дніпропетровської обласної лікарні. Актуальні проблеми автоматизації та інформаційних технологій. Том 21. 2017. С. 87-94.

5. Качур О.Ю. Оцінка організаторами охорони здоров'я стану та перспектив розвитку променевої діагностики у закладах охорони здоров'я вторинного рівня // Україна. Здоров'я нації. Випуск 4/1(41). 2016. С. $122-126$.

6. Ковалишин О.С. Продукційна система нечіткої логіки для оптимізації планів відновлювальної терапії : дисертація на здобуття наукового ступеня кандидата технічних наук. Системи та засоби штучного інтелекту. Міністерство освіти i науки України, Національний університет “Львівська політехніка". Львів, 2019. С. $137-148$.

7. Медичні кадри та мережа закладів охорони здоров'я системи MO3 України за 2017-2018 роки. Центр медичної статистики MO3 України. URL: http://medstat.gov.ua/ukr/statdov.html.

8. Медичні кадри та мережа закладів охорони здоров'я системи MO3 України за 2016-2017 роки. Центр медичної статистики MO3 України. URL: http://medstat.gov.ua/ukr/statdov.html.

9. Особливості планування функції та структури відділень екстреної (невідкладної) медичної допомоги багатопрофільних лікарень на основі досвіду США // Іскра Н.І., Печиборщ В.П., Кузьмін В.Ю. // URL: http:/lib.inmeds.com.ua:8080/jspui/bitstream/lib/1426/1/Особливості\% 20планування\%20функції\%20та\%20структури\%20відділень\%20ЕМД\%20б агатопрофільних\%20лікарень\%20на\%20основі\%20досвіду\%20США.pdf.

10. Парій В.Д. Основні підходи до визначення лікарні інтенсивного лікування при створенні госпітального округу. Україна. Здоров'я нації. 2016. № 3. C. 59-64. URL: http://nbuv.gov.ua/UJRN/Uzn_2016_3_13. 
11. Порохня В.М. Модель максимізації функції корисності діяльності установи на основі сценаріїв розвитку. Держава та регіони: серія економіка та підприємництво. 2016. Випуск 6(93). С. 77-81.

12. Про затвердження переліків закладів охорони здоров'я, лікарських, провізорських посад і посад молодших спеціалістів із фармацевтичною освітою у закладах охорони здоров'я, поточна редакція від 06.07.2018. Наказ Міністерства охорони здоров'я України 28.10.2002 № 385. URL: https://zakon.rada.gov.ua/laws/show/z0892$02 \#$ 28.

13. Стецюк В.3. Інформаційна система для медико-генетичної лабораторії. Медична інформатика та інженерія. 2016. Випуск 2. C. 55-57.

14. Шинкарук Ю.І. Шляхи оптимізації роботи середнього медичного персоналу терапевтичного відділення. Медсестринство. 2018. Випуск (2). https://doi.org/10.11603/2411-1597.2017.2.8510.

\section{Information about authors:}

Tolstanov O. K.,

Doctor of Medical Sciences, Professor, Professor at the Department of Health Management Shupyk National Medical Academy of Postgraduate Education 9, Dorogozhyzkaja str., Kyiv, 04112, Ukraine

Shchyrina K. V., $\mathrm{PhD}$ Student in the Department of Health Management Shupyk National Medical Academy of Postgraduate Education 9, Dorogozhyzkaja str., Kyiv, 04112, Ukraine 